\title{
MICROTUBERS OF POTATO (SOLANUM TUBEROSUM L.) : IN VITRO CONSERVATION AND TISSUE CULTURE
}

\author{
D. P. PREMATILAKE* and M. H. MENDIS \\ Plant Genetic Resources Centre, Gannoruwa, Peradeniya
}

(Received: 29 September 1997; accepted: 08 January 1999)

\begin{abstract}
Potato (Solanum tuberosum L.) microtubers are a valuable source for germplasm conservation and disease-free germplasm exchange. Microtuber induction potential of 32 potato cultivars were tested under in vitro conditions. Microtubers from 06 potato cultivars were stored at $4^{\circ} \mathrm{C}$ for 3 years and planted in soil. It was observed that tubers retained their viability under low temperature when tuber diameter was $>5 \mathrm{~mm}$. Such tubers produced healthy plantlets upon transfer to soil. Callusing and shoot initiation occurred from microtuber-core explants with different varietal response. Plants were recovered from these shoots by culturing in hormone-free growth medium.
\end{abstract}

Key words : Callogenesis, conservation, microtubers, potato, regeneration

\section{INTRODUCTION}

Potato is one of the world's most economically important tuber crops, belonging to the family Solanaceae. In Sri Lanka, potato is grown over an area of 7000 ha and the annual seed potato requirement is nearly 15,000 tonnes. ${ }^{1}$ The conventional method of potato propagation is by seed tubers, which has the disadvantage of being contaminated with disease-causing pathogens. In vitro rapid multiplication of disease-free planting material provides a solution to this problem. Such material facilitates germplasm movement in quarantine aspects. The parental stocks can be maintained in vitro to ensure a clean source of plants from which tubers can be produced.

Microtubers of potato, formed in vitro, are small, less in weight and thus, handling in transportation and storage is easier in comparision to conventional seed potatoes. They are produced in place of axillary buds when potato shoot cultures are grown in the presence of high levels of sucrose. ${ }^{2}$ Since microtubers are formed under aseptic conditions, they are free from disease-causing pathogens. Electrophoretic protein patterns in tubers have shown no appreciable genetic differences detected among field-grown tubers and in vitro - induced microtubers of potato. ${ }^{3}$ Therefore, microtubers are an excellent source for disease-free germplasm. exchange of potato. Microtubers reduce the time taken to produce seed tubers, reduce the number of field generations required and hence result in higher quality seed tubers. ${ }^{2}$

\footnotetext{
* Corresponding author
}

Abbreviations : GA (Gibberellic acid), CCC (Cholochlorine chloride), NAA (Naphthalene Acetic Acid), BAP (Benzyl Amino Purine), IAA (Indole-3-Acetic Acid), 2iP ( $\mathrm{N}^{6}-(\delta$ 2-isopentenyl adenine) 
Genetic improvement of a plant depends mainly on the availability and efficient induction of genetic variability. Some tissue culture technologies facilitate generation of somaclonal variation, which can be a useful tool in causing genetic changes, especially in a vegetatively propagated crop like potato. Earlier studies have revealed that somaclonal variation of potato has resulted in resistance to early blight ${ }^{4}$ and changes in tuber colour and flower colour. ${ }^{5.6}$ Callogenesis and plant regeneration from cultured tissue explants are basic requirements for the application of tissue culture for genetic enhancement of potato. Potato plants can be regenerated from explants such as leaves, stems, petioles and tubers following an intermediate callus phase. In addition, plants can be regenerated from protoplasts which have more variability than those directly regenerated from cxplants. ${ }^{2}$ More recent work has confirmed that in vitro shoot regencration of Solanum species is genetically controlled ${ }^{7}$ and hence it is essential to have a prior knowledge on the explant behaviour in culture and regeneration requirements. Since microtubers are disease-free materials, they are suitable to be used in tissue culture studies.

Within this context, studies were performed to find out the microtuber induction potential of 32 potato cultivars, to use microtubers as a source for germplasm conservation and to understand callogenesis and in vitro plant regeneration capability of microtuber explants:

\section{METHODS AND MATERIALS}

\section{Microtuber induction potential of potato}

Shoots $(3-4 \mathrm{~cm})$ were obtained from in vitro - grown mother plants of 32 potato cultivars (Table1). These shoots were cultured in $\mathrm{MS}^{\varsigma}$ - based liquid $\mathrm{M}_{1}$ medium (Table 2) in glass tubes (1 shoot $/ 5 \mathrm{ml}$ medium; $5-7$ shoots / cv.). Cultures were maintained at $25^{\circ} \mathrm{C}$ under fluorescent light $\left(40 \mu \mathrm{Es}^{-1} \mathrm{~m}^{-2} ; 10 \mathrm{~h}\right)$ to promote plantlet development. After 2-3 weeks, $M_{2}$ medium, designated for microtuber inductión ${ }^{3}$, was incorporated into culture tubes $(6 \mathrm{ml} /$ tube) and the tubes were transterred to a dark room at $18^{\circ} \mathrm{C}$. After 4-5 weeks, microtubers were harvested and recordings were made on tuber diameter, tuber weight and number of tubers per plant. 
Table 1: Potato cultivars used for microtuber induction.

\begin{tabular}{c|c}
\hline Cultivar name & Cultivar name \\
\hline P-55.7 & Muru \\
Pamina & $($ VTN $2-62-33.3$ \\
225.1 & $397 \mathrm{~B}$ \\
Murca & San Juan \\
Saturna & CEF 67.1 \\
R-128.6 & L:46/3 \\
Mex 771949 & Chiquita \\
Serrana Inta & Atzimba \\
Atlantic & Wauseon \\
I-1039 & G-1 \\
TS-2 & 394 \\
$17 / 13$ & 381388.34 \\
BR:112-113 & A44 \\
KTT-60.21.19 & ASN 69.1 \\
G-6 & Gesiree \\
Apollo & \\
\hline
\end{tabular}

Microtubers as a source of potato germplasm conservation

After harvesting, microtubers were washed with sterilized distilled water and wiped dry with pre-autoclaved filter papers. Tubers were then put into small, sterilized screw-capped glass vials $(25 \mathrm{ml})$ and stored under dark conditions at $4{ }^{\circ} \mathrm{C}$. Microtubers (2-8 mm diameter) of 6 potato cultivars (5-10 tubers / cultivar) were used for this study.

Three years later, tubers were transferred to ambient temperature $\left(25 \pm 1^{\prime \prime} \mathrm{C}\right)$. One week afterwards, these microtubers were planted in a mixture of sand and compost (2:1) in $5 \mathrm{~cm}$ plastic pots. Recordings were made on the number of microtubers germinated after 6 weeks of planting. 
Callogenesis and plant regeneration ability of microtuber explants

Microtubers of 6 potato cultivars were tested for their ability in initiate calli and subsequent plant regeneration. Explants were prepared by removing the outer surface of tubers and cutting the tuber-core into square pieces $\left(0.5 \times 0.5 \times 0.1 \mathrm{~cm}^{3}\right)$. These explants were cultured on $M_{3}$ medium (Table 2) in $9 \mathrm{~cm}$ Petri dishes (5-6 explants / $25 \mathrm{ml}$ medium; 5 Petri dishes/ cultivar). Cultures were incubated at $25^{\circ} \mathrm{C}$ at $40 \mu \mathrm{Es}^{-1} \mathrm{~m}^{-2}$ for $10 \mathrm{~h}$. Three and 6 weeks after culturing, recordings were made on the number of explants with callus, number of calli with shoots and the total number of shoots produced from each cultivar. Shoots regenerated thus, were separated from mother explants and cultured on agar-solidified $M_{4}$ medium (Table 2) in glass jars (2-3 shoots/ $25 \mathrm{ml}$ medium) to promote plant development.

Table 2: Composition of $M_{1}, M_{2}, M_{3}$, and $M$, media used for shoot cultures,microtuber induction, shoot regeneration from tuber-core explants and plant development of potato.

\begin{tabular}{|c|c|c|c|c|}
\hline \multirow[t]{2}{*}{ COMPONEN'T } & \multicolumn{4}{|c|}{ CULTURE MEDIUM CONCENTRATION (mgl') } \\
\hline & $\mathbf{M}_{1}$ & $\mathbf{M}_{2}$ & $\mathbf{M}_{3}$ & $\mathbf{M}_{4}$ \\
\hline MS inorganic salts & $\mathrm{x} 1 / 2$ & $\mathrm{x} 1$ & $\mathrm{x} 1$ & $\mathrm{x} 1$ \\
\hline Nicotinic acid & 5.0 & 5.0 & 5.0 & 5.0 \\
\hline Pyridoxin $\mathrm{HCl}$ & 0.5 & 0.5 & 0.5 & 0.5 \\
\hline Thiamin $\mathrm{HCl}$ & 0.5 & 0.5 & 1.0 & 0.5 \\
\hline Glycine & 2.0 & 2.0 & 2.0 & 2.0 \\
\hline Biotin & 0.05 & 0.05 & - & 0.05 \\
\hline Inositol & 100.0 & 100.0 & 100.0 & 100.0 \\
\hline Sucrose $(\% \mathrm{w} / \mathrm{v})$ & 3.0 & 15.0 & 3.0 & 2.0 \\
\hline IAA & - & - & 0.5 & - \\
\hline Zeatin $^{\mathrm{a}}$ & - & - & 1.7 & - \\
\hline $\operatorname{Agar}(\% \mathrm{w} / \mathrm{v})$ & - & - & 0.8 & 0.8 \\
\hline $\mathrm{pH}$ & 5.7 & 5.7 & 5.9 & 5.8 \\
\hline
\end{tabular}

${ }^{a}$ Added after autoclave sterilization 


\section{RESULTS}

\section{Microtuber induction}

All potato cultivars tested induced microtubers under in vitro condtions (Figure 1). Average number of microtubers varied between 1-3 per plant (Table 3). Tuber size ranged from $2 \mathrm{~mm}$ to $8 \mathrm{~mm}$ in diameter whereas tuber weight was between 0.03 $0.28 \mathrm{~g} /$ tuber. The results suggested that all tested cultivars of potato have microtuber induction potential under the described conditions and within 4-5 weeks, but tuber size and number varied within and between cultivars (Figure 2).

\section{Microtubers for germplasm conservation}

Tubers retained their viability, when the tuber size was $>5 \mathrm{~mm}$. This was a common feature for all 6 cultivars subjected to low temperature storage. Tubers smaller than $5 \mathrm{~mm}$ were shrunken after 3 years of storage and failed to convert back to rigidity even when kept at room temperature at high humidity ( $\mathrm{RH}>75 \%$ ). In contrast, tubers $>5 \mathrm{~mm}$ were firm, round and healthy in appearance. Such tubers germinated quickly when transferred to soil and produced healthy shoots (Table 4).

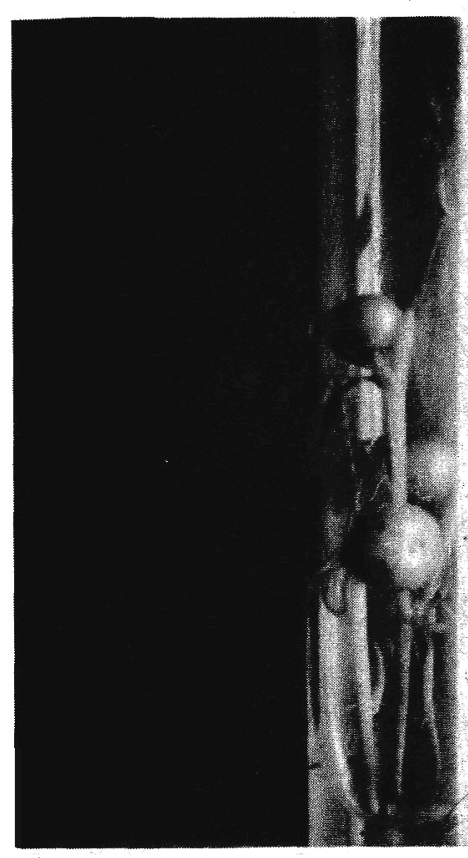

(a)

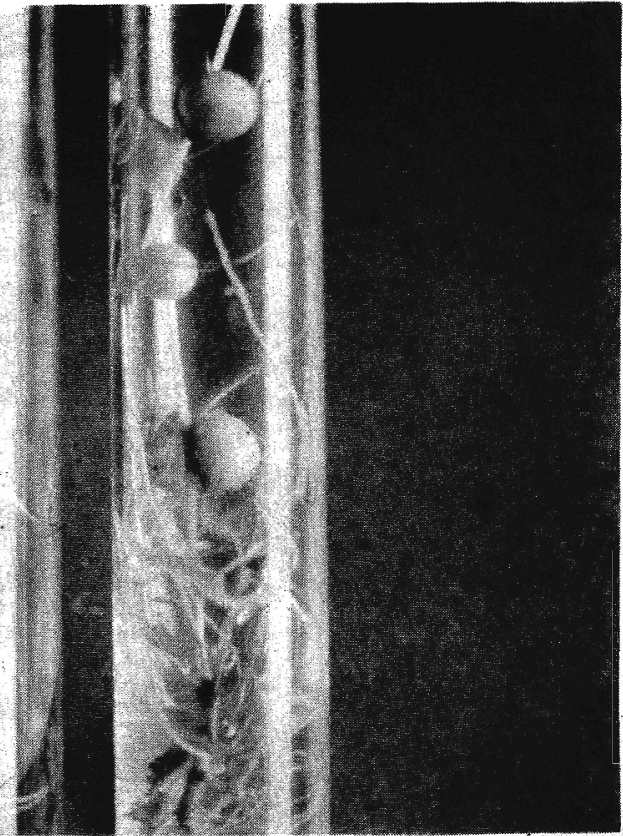

(b)

Figure 1: Induction of microtubers of potato (cvs. a. Desiree and b. I-1039) under in vitro conditions ( $x 0.8$ ). 


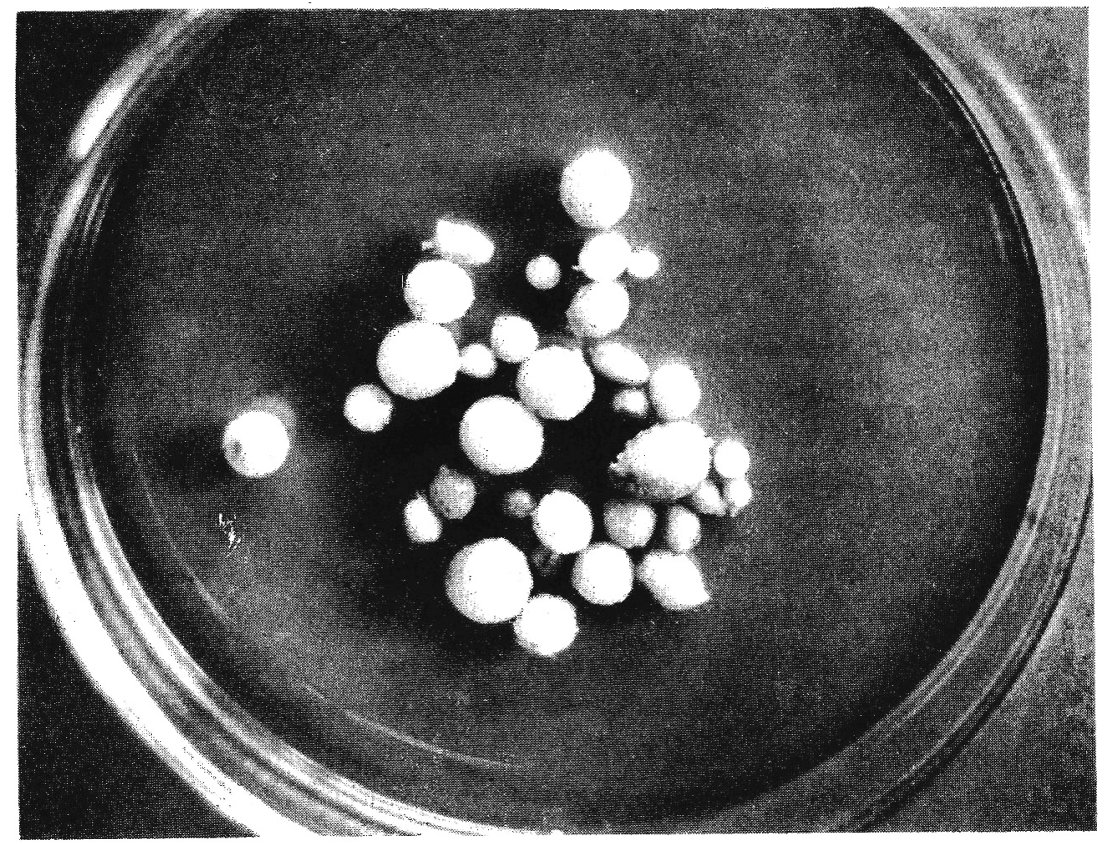

Figure 2: Variation in microtuber size of potate (N. IItuseon ( 60.8$)$.

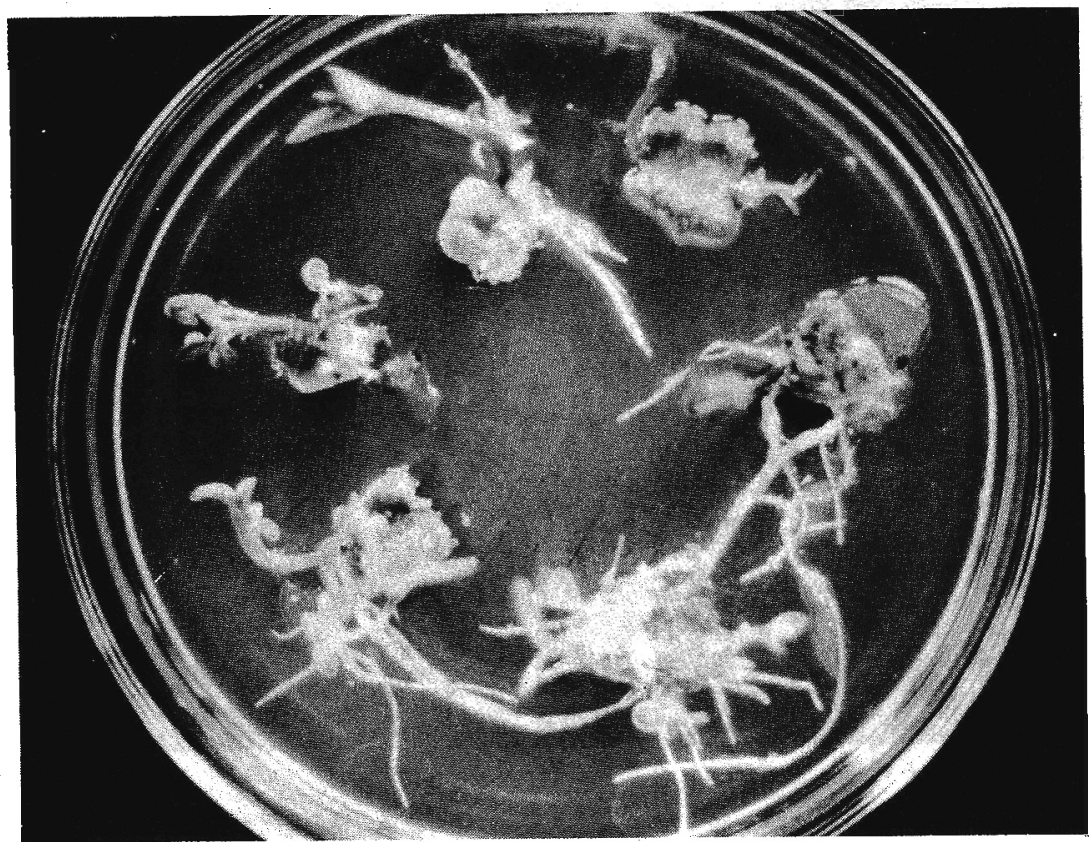

Figure 3: Shoot regeneration from microtuber - core explants of potato cv. Atzimba in $\mathrm{M}_{3}$ medium ( $\mathrm{x} 0.8$ ) 
Table 3: Characteristics of microtubers of tested potato cultivars.

\begin{tabular}{|c|c|c|c|}
\hline Cultivar name & $\begin{array}{l}\text { Average number of } \\
\text { tubers per plant }\end{array}$ & $\begin{array}{c}\text { Tuber } \\
\text { diameter } \\
(\mathrm{mm} \pm \mathrm{sd})\end{array}$ & $\begin{array}{l}\text { Tuber weight } \\
\qquad(\mathrm{g} \pm \mathrm{sd})\end{array}$ \\
\hline P-55.7 & 1.8 & $5 \pm 2$ & $0.09 \pm 0.08$ \\
\hline Pamina & 1.5 & $7 \pm 2$ & $0.22 \pm 0.09$ \\
\hline 225.1 & 1.5 & $7 \pm 2$ & $0.28 \pm 0.17$ \\
\hline Murca & 1.0 & $6 \pm 1$ & $0.18 \pm 0.03$ \\
\hline Saturna & 1.0 & $6 \pm 1$ & $0.14 \pm 0.08$ \\
\hline $\mathrm{R}-128.6$ & 1.0 & $4 \pm 1$ & $0.09 \pm 0.07$ \\
\hline Mex 771949 & 2.0 & $3 \pm 1$ & $0.03 \pm 0.02$ \\
\hline Serrana Inta & 3.0 & $6 \pm 2$ & $0.16 \pm 0.14$ \\
\hline Atlantic & 3.0 & $4 \pm 3$ & $0.09 \pm 0.11$ \\
\hline I-1039 & 2.5 & $6 \pm 3$ & $0.23 \pm 0.26$ \\
\hline TS-2 & 1.0 & $5 \pm 1$ & $0.15 \pm 0.07$ \\
\hline $17 / 13$ & 1.0 & $4 \pm 1$ & $0.07 \pm 0.01$ \\
\hline BR:112-113 & 1.5 & $6 \pm 2$ & $0.16 \pm 0.10$ \\
\hline KTT-60.21.19 & 2.0 & $6 \pm 2$ & $0.16 \pm 0.12$ \\
\hline $\mathrm{G}-6$ & 1.0 & $5 \pm 1$ & $0.18 \pm 0.01$ \\
\hline Apollo & 1.5 & $7 \pm 2$ & $0.23 \pm 0.20$ \\
\hline Muru & 1.0 & $3 \pm 1$ & $0.03 \pm 0.01$ \\
\hline (VTN) 2-62-33.3 & 3.0 & $3 \pm 1$ & $0.09 \pm 0.01$ \\
\hline $397 \mathrm{~B}$ & 1.0 & $2 \pm 1$ & $0.02 \pm 0.01$ \\
\hline San Juan & 2.5 & $4 \pm 2$ & $0.19 \pm 0.08$ \\
\hline CEF 67.1 & 2.0 & $5 \pm 2$ & $0.15 \pm 0.12$ \\
\hline
\end{tabular}


Table 1 cont.

\begin{tabular}{lccc}
\hline Cultivar name & $\begin{array}{c}\text { Average number of } \\
\text { tubers per plant }\end{array}$ & $\begin{array}{c}\text { Tuber } \\
\text { diameter } \\
(\mathrm{mm} \pm \mathrm{sd})\end{array}$ & $\begin{array}{c}\text { Tuber weight } \\
(\mathrm{g} \pm \mathrm{sd})\end{array}$ \\
\hline L:46/3 & 3.0 & $5 \pm 2$ & $0.14 \pm 0.02$ \\
Chiquita & 2.0 & $5 \pm 1$ & $0.14 \pm 0.02$ \\
Atzimba & 3.0 & $6 \pm 3$ & $0.19 \pm 0.18$ \\
Wauseon & 3.0 & $6 \pm 2$ & $0.18 \pm 0.15$ \\
G-1 & 3.0 & $7 \pm 2$ & $0.20 \pm 0.18$ \\
394 & 3.0 & $6 \pm 2$ & $0.10 \pm 0.07$ \\
381388.34 & 2.0 & $7 \pm 2$ & $0.28 \pm 0.23$ \\
444 & 2.2 & $8 \pm 1$ & $0.22 \pm 0.07$ \\
ASN 69.1 & 2.0 & $7 \pm 2$ & $0.23 \pm 0.09$ \\
G-5 & 1.0 & $6 \pm 3$ & $0.19 \pm 0.17$ \\
Desiree & 3.0 & $5 \pm 2$ & $0.21 \pm 0.15$ \\
\hline
\end{tabular}

Table 4: Microtuber ( $>5 \mathrm{~mm}$ ) germination in soil after 3 years of storage at $4^{4} \mathrm{C}$ under complete darkness .

\begin{tabular}{lccc}
\hline Cultivar & $\begin{array}{c}\text { Number of } \\
\text { tubers planted }\end{array}$ & $\begin{array}{c}\text { Number of tubers } \\
\text { germinated }\end{array}$ & $\begin{array}{c}\text { Plant } \\
\text { appearance }\end{array}$ \\
\hline P-55.7 & 05 & 05 & Healthy \\
MEX 771949 & 08 & 08 & Healthy \\
Pamina & 06 & 06 & Healthy \\
Atlantic & 10 & 09 & Healthy \\
R-128.6 & 08 & 08 & Healthy \\
Desiree & 08 & 08 & Healthy \\
\hline
\end{tabular}




\section{Callogenesis and plant regeneration}

White-pale green calli were initiated at the cut surfaces of explants, 14 days after initial culture. A cultivar difference was observed in callus formation at the 3rd week, but by the 6 th week, this difference was diminished (Table 5). Plant regeneration capacity was high in cvs. 381388.34 and Atzimba which was observed even at the $3 \mathrm{rd}$ week (Figure 3 ). On the other hand, cv. 444 exhibited a poor regeneration potential. Cvs. Atzimba, G-1 and Wauseon possessed many regenerated shoots (Table 5 ).

Table 5: Callusing and plant regeneration of potato microtuber -core explants in $M_{3}$ medium at the 3rd and 6 th week.

\begin{tabular}{|c|c|c|c|c|c|}
\hline \multirow[t]{2}{*}{ Cultivar } & \multicolumn{2}{|c|}{$\begin{array}{c}\text { Explants with } \\
\text { callus } \\
(\%)^{i \prime}\end{array}$} & \multicolumn{2}{|c|}{$\begin{array}{c}\text { Calli } \\
\text { with shoots } \\
(\%)^{b}\end{array}$} & \multirow{2}{*}{$\begin{array}{c}\text { Number of } \\
\text { shoots per } \\
\text { callus }\end{array}$} \\
\hline & 3 weeks & 6 weeks & 3 weeks & 6 weeks & \\
\hline 381388.34 & 67 & 100 & 67 & 100 & 2.0 \\
\hline Atzimba & 100 & 100 & 67 & 100 & 3.9 \\
\hline G-1 & 100 & 100 & 33 & 100 & 2.5 \\
\hline 444 & 100 & 100 & - & 11 & 2.0 \\
\hline Serrana Inta & 67 & 100 & 33 & 67 & 1.0 \\
\hline Wauseon & 33 & 100 & 33 & 67 & 3.7 \\
\hline
\end{tabular}

a : Explants with callus $(\%)=$ (Calli producing number of explants $/$

Number of explants cultured) $\times 100$

b : Calli with shoots $(\%)=($ Number of calli with regenerated shoots $/$

Number of explants with calli)x 100

${ }^{c}:$ Number of shoots per callus $=$ Number of shoots $/$ Number of calli with regenerated shoots $) \times 100$

\section{DISCUSSION}

Factors such as the explant, culture medium and incubation temperature on in vitro propagation, tuberization and storage of tuberlets have been evaluated. ${ }^{9}$ Enhanced tuberization has been observed with stem cuttings by propagation on the MS medium with the macro nutrient at twice the published concentrations and further supplemented with thiamin $\mathrm{HCl}\left(0.05 \mathrm{mgL}^{-1}\right)$, nicotinic acid $\left(0.05 \mathrm{mgL}^{-1}\right)$, pyridoxin $\mathrm{HCl}\left(0.1 \mathrm{mgL}^{-1}\right)$, glycine $\left(2.0 \mathrm{mgL}^{-1}\right)$, coconut water $(10 \% \mathrm{v} / \mathrm{v})$ and 
sucrose $(4 \% \mathrm{w} / \mathrm{v})$. Subsequent induction and growth of these tuberlets have been achieved $\left(10-22^{\circ} \mathrm{C}\right)$ with MS containing BAP $\left(1.0 \mathrm{mgL}^{-1}\right)$, coumarin $\left(50 \mathrm{mgL}^{-1}\right)$, coconut water $(10 \% \mathrm{v} / \mathrm{v})$ and sucrose $(8 \% \mathrm{w} / \mathrm{v})$. Previously it was reported ${ }^{10}$ that MS medium supplemented with $\operatorname{BAP}\left(0.5 \mathrm{mgL}^{-1}\right), \mathrm{GA}_{3}\left(0.4 \mathrm{mgL}^{-1}\right)$ and NAA $\left(0.01 \mathrm{mgL}^{-1}\right)$ for propagation phase and same medium containing BAP $\left(5.0 \mathrm{mgL}^{-1}\right)$, $\mathrm{CCC}\left(500 \mathrm{mgL}^{-1}\right)$ and sucrose $(8 \% \mathrm{w} / \mathrm{v})$ for the tuberization phase. On the average, about 10 tuberlets per vessel were obtained in 4 weeks following maintenance -in the dark. Recent studies have shown that MS medium without growth regulators favoured the production of microtuber $\mathrm{s}^{11}$ and tuber bulking was better in dark than in light.

A higher yield of tuberlets (50 tuberlets/vessel) has been reported ${ }^{12}$ using MS medium supplemented with NAA $\left(0.005 \mathrm{mgL}^{-1}\right)$ for propagation of shoots and MS with BAP $\left(10.0 \mathrm{mgL}^{-1}\right)$ and sucrose $(8 \% \mathrm{w} / \mathrm{v})$ for tuberization but tuberlets were formed in 16 weeks. All these studies were primarily aimed at developing protocols for tuberlet production although storage of such tuberlets retaining viability for 12 months at $18-22^{\circ} \mathrm{C}$ in test tubes lined with cotton wad has been reported. ${ }^{9}$ The present study showed the possibility of extending storage life of microtubers for a period of 3 years at low temperature $\left(4^{\circ} \mathrm{C}\right)$ although 1-3 tuberlets per plant were obtained.

Storage ability of microtubers at low temperature simplifies germplasm conservation of potato. This method of storing is further attractive as it is safer than field maintenance and since no subculturing is involved (as in in vitro plant conservation), more simple and less time consuming. Since all cultivars behaved in a similar manner under darkness at $4^{\circ} \mathrm{C}$, this protocol is suitable for establishment of a potato germplasm gene bank with microtubers. It is reported that under these conditions, varietal characteristics of potato retained the ability to regenerate genetically identical plants. ${ }^{13}$ In addition, all tested potato cultivars suggested that these tubers have the potential to behave as an alternative to seed potatoes. Small size of these tubers make them particularly attractive in germplasm exchange programmes where storage and transportation of bulky quantities of potato tubers or delicate in vitro plantlets is difficult. During transport microtubers can withstand more prolonged dark periods, rougher handling and wider range of temperatures compared to in vitro shoot cultures. On the other hand, microtubers can be produced in the laboratory year around and stored until request is made.

Capacity for in vitro tuber formation is considered as a varietal characteristic $^{14}$ and the variations such as tuber size and tuber weight may be linked with the same inherent genetic mechanism which usually controls these characters of potato. A QTL (Quantitative Trait Loci) analysis of potato has shown that 11 distinct loci on seven chromosomes were associated with variation in tuberization. ${ }^{15}$ 
A difference in plant regeneration capacity of leaf and rachis tissues of diploid and tetraploid genotypes of potato was reported. ${ }^{16}$ Media containing IAA $\left(1.0 \mathrm{mgL}^{-1}\right)$ and BAP $\left(0.25 \mathrm{mgL}^{-1}\right)$ or $2 \mathrm{iP}\left(0.25 \mathrm{mgL}^{-1}\right)$ favoured callus formation and shoot differentiation only with the diploid genotypes. Alternatively, plants have been regenerated from tuber discs of potato using three growth media. Cytokinin in the first medium was essential for shoot meristem formation and BAP was found to be the most effective. As $\mathrm{GA}_{3}$ was essential for both shoot formation and development, it was included in the second medium.. Rooting of isolated shoots occurred in a third medium which was free of hormones. ${ }^{17.18}$ In the present study, only two media were used for plantlet production from tuber-core tissues of potato. $M_{3}$ medium, which contained zeatin and IAA was used for shoot initiation, hormone-free $\mathrm{M}_{4}$ medium for root formation and subsequent growth of isolated shoots. The results suggested that microtuber tissues can be used for tissue culture-based potato improvement programmes although varietal differences in shoot regeneration capacity are found.

\section{References}

1. Samarasinghe P. W. S. M. (1993) Seed potato production through rapid multiplication techniques. In : Biotechnology in agricultural development. (Ed. P. Ganashan \& S. Balendira ) pp. 55-60. Department of Agriculture, Sri Lanka.

2. Jones M. G. K. (1994). In vitro culture of potato. In : Plant cell and tissue culture. (Ed. I. K. Vasil \& T. A. Thorpe) pp . 363-378, Kluwer Academic Publishers, Netherlands.

3. Rajapakse D. P., Imai T. \& Ishige T. (1991). Analysis of potato microtuber proteins by sodium dodecylsulfatepolyacrylamide gel electrophoresis. Potato Research $34: 285-293$

4. Shepard J. F., Bidney D. \& Shahin E. (1980). Potato protoplasts for crop improvement. Science 208: $17-24$

5. Evans N. E., Foulger D., Farrer L., Risiott R. \& Bright S. W. J. (1986). Variation in explant-derived potato clones over three tuber generations. Euphytica $35: 353-361$

6. Wheeler V. A., Evans N. E., Foulger D., Webb K. J., Karp A., Frankling J. \& Bright S. W. J. (1985). Shoot formation from explant cultures of potato and an examination of chromosomes and morphological variation in the regenerated plants. Annals of Botany 55 : 309 - 320

7. Sint Jan V van, Laublin G., Birhman R. K. \& Cappadocia M. (1996). Genetic analysis of leaf explant regenerability in Solanum chacoense. Plant Cell Tissue and Organ Culture 47 (1): $9-13$ 
8. Murashige T. \& Skoog F. (1962). A revised medium for rapid growth and bioassays with tobacco tissue cultures. Physiologia Plantarum 15 : 473-497

9. Paet C. N. \& Zamora A. B. (1991). In vitro tuberization in potato (Solanum tuberosum L.) using different protocols and storage of tuberlets. Philippine Agriculture 74 (1) : 59-70

10. Tover P., Estrada R., Schilde-Rentschler L. \& Dodds J. H. (1985). Induction and use of in vitro potato tubers. CIP Circular 13 (4) : $1-5$

11. Badawi M. A., El-Sayed S. F., Edriss N. H. \& El-Barkouki T. M. (1996). Factors affecting production of potato micro tubers from meristem tip in vitro. Egyptian Journal of Horticulture 22 (2) : 137 - 149

12. Wang P. \& Hu C. (1982). In vitro mass tuberization and virus-free seed potato production in Taiwan. Amsterdam Potato Journal 59: 33-37

13. Lichkov A. \& Dimitrova D. (1995). Maintenance of Bulgarian and introduced potato varieties in vitro for breeding purposes. Rasteniev "dni Nauki $32(1 / 2): 146-148$

14. Dimitrova D., Lichkov A. \& Kilifarska M. (1995). Effect of different temperature regimes on the long-term storage of potato in vitro. Rasteniev " dni Nauki 32 (3) : 60-62

15. Berg J H van den., Ewing E. E., Plaisted R. L., McMurry S. \& Bonierbale M. W. (1996). QTL analysis of potato tuberization. Theoretical and Applied Genetics 93 (3) : $307-316$

16. Chandra R., Upadhya M. D. \& Jha K. K. (1985). Regeneration of plants from leaf and rachis tissues of the potato in vitro. Journal of Indian Potato Association $12: 88-91$

17. Jarret R. L., Hasegawa P. M. \& Erickson H. T. (1980a). Effect of medium components on shoot formation from cultured tuber discs of potato. Journal of American Society of Horticultural Science 105 : 238-242

18. Jarret R. L., Hasegawa P. M. \& Erickson H. T. (1980b). Factor's affecting shoot initiation from tuber discs of potato (Solanum tuberosum L.). Physiologia Plantarum 49 : 177-184 